\title{
Students' Characteristics and Level of Academic Performance in Estate Management Department, Federal University of Technology, Akure: The Nexus
}

\author{
Nnaemeka B. EZEOKOLI ${ }^{1} \quad$ Oladotun N. AGBOOLA ${ }^{1 *} \quad$ Odedapo O. ATERE $^{2}$ \\ 1.Department of Estate Management, Federal University of Technology, Akure, Nigeria \\ 2.Department of Estate Management and Valuation, Rufus Giwa Polytechnic, Owo, Nigeria
}

\begin{abstract}
Academic performance is one of the yardsticks in measuring the performance of Professionals in various disciplines. Thus, it ought to be given optimum attention lest educational institutions produce professionals that are below required standards. Therefore, this research assesses the factors that affect the academic performance of the Students of Estate Management, FUTA. In order to achieve this, the study examined the characteristics of students admitted into Estate Management Department, FUTA, their level of academic performance between 2007 and 2016, and analyzed the factors that affect their academic. Data was drawn from 131 students in 200 level, 300 level and 500 level. The analysis was carried out using percentage frequency table, graph and multiple regression analysis. From the research, it was found that, between 2007 and 2016, majority of the Students graduated with second class lower division. Academic performance was also significantly $(\mathrm{p}<0.05)$ affected by age of Students, parental support, number of hours devoted for personal reading and number of units in place of worship. It is recommended that Parents should be made aware of their roles in the success of their wards/children, while students themselves are to be self-motivated so as to cultivate good reading habits. This will enhance their academic performance and at the long run, prepare students for the demands of the Estate Surveying and Valuation profession.
\end{abstract}

Keywords: Academic Performance, Analysis, Estate Management, Factors, Students.

DOI: $10.7176 / \mathrm{JEP} / 12-27-06$

Publication date:September $30^{\text {th }} 2021$

\section{Introduction}

Academic performance is often defined in terms of examination performance of students (Cambridge University Report, 2003).Comfort, Fwangkat, Shalkur andAdeniyi(2014) views it as the way and manner students deal with their studies, and how they cope with or accomplish different tasks given to them by teachers or lecturers. However, it should be noted that Students academic performance is not only paramount to students, but to every institution as well as other stakeholders whose interest is to see the best from the students e.g. parents, guardians, sponsors as well as the society or government. Hoyle (1986) argued that schools are established with the aim of imparting knowledge and skills to those who go through them, and that is evidenced by their academic performance. Thus, the Students' Cumulative Grade Point Average (CGPA) was seen as an objective tool for assessing the performance of students in higher institutions of learning (Bacon \& Bean, 2006; Kobrin, Shaw, Mattern\&Barbuti, 2008). Furthermore, Sujit(2006) affirmed that the GPA still remains the most common factor used by administrators to evaluate progression in all academic environments.

Despite the funds channeled into the Nigerian education system and the high quality Lecturers, majority of the students perform averagely, while some perform poorly and/or even asked to withdraw from the institution without having any result. Only a few perform outstandingly. This is a very big reason to worry as some of the Parents of these students struggle to pay their tuition fees and expects the best to come out of the input they have made on their children's education. Thus, the investigation into the academic performance of students have attracted the interest of most stakeholders in the education sector in Nigeria because of the public out cries concerning the low standard of education in the country, and the standard of graduates churned out yearly into the larger society (Sogbetun, 1981).

Actually, numerous factors have been linked to the performance of students in Nigeria Universities. More so that their academic performance has far-reaching implications on their personal and professional lives. To some extent, it impacts on their career choice, personal income and level of success, as well as their degree of participation in community life. A number of personal and social factors have been observed to influence academic performance. For instance, Park \& Kerr (1990) identified some factors such as family income, selfmotivation, inability to manage school work and students' personal circumstances amongst others to have contributed to the declining performance of many students, though with varying levels of impact. Admittedly, the performance of students can be attributed to a host of factors and may include; student factors, institutional factors, lecturers' factor etc.

In recent years, more students have graduated with low grade level from tertiary institutions, while some 
who were admitted do not have the patience and or Will to stay to the end of four or five years programme. Some change to other departments due to poor academic performances or they drop out of the programme all together (Ali,2013). Accordingly, turning out graduates with mass failure or poor academic standing makes them unable to successfully fit into the Sustainable Development Programme of the nation or world.

The issue of poor academic performance of students especially in Nigeria has become a source of concern to most parties involved in the delivery of quality education within the country as prospective professionals who perform poorly today may end up making vital decisions in the profession in years to come. Thus, this study seeks to examine the academic performance of Estate Management Students in the Federal University of Technology, Akure between 2007 and 2016, and identify the factors associated with the students' performance, because understanding these factors will go a long way in improving the academic standards of the Universities.

\subsection{Literature Review}

Educators and researchers have long been interested in identifying and understanding the variables that contribute to academic excellence. As students progress from admission to graduation, a complex interaction of some factors tends to influence the quality of their academic performances and experiences. A number of studies have been carried out to identify the numerous factors that affect academic performance in various centres of learning. The investigations into these factors have attracted the interest of most stakeholders in the education sector in Nigeria because of the public outcries concerning the low standard of education in the country (Sogbetun, 1981).Some of these factors have been attributed class size and institution's failure to create the environment that is accommodating and conducive to learning and educational needs (Harb\& El-Shaawari, 2006); Heineesen, 2010). However, some of these factors are also connected with the student's will and character towards education and learning. For instance, Kraft and Singhapakdi (1991) opined that students who performed better than their peers are those whose work ethics are strong, and are strongly committed to their work. Zimmerman, Bandura and Martinez-Pons (1992) included students' academic background, changing academic goal, inability to manage normal schoolwork and lack of basic and fundamental skills as the determinants of students' academic performance according. The impacts of these determinants vary with context and not all factors are relevant for a particular context. Apart from the above factors, students' attitudes toward their studies can go a long way in affecting their performances. For instance, Romer (1993) noted how regularity in class could improve students' performance as they get first-hand information from the lecturers. Thus, students themselves play critical roles in getting good grades and must therefore explore all opportunities available within their academic environment.

Crosnoe, Johnson and Elder (2004) identified 32 factors that could affect students success in general. Among these factors are those and they include: fear; anxiety; confidence; concentration; health and wellbeing, social factors: peer group; family background; religion; home problems e.g. Break ups of parent; infrastructure for learning; personal or family crisis, economic factors: financial problem and stress, environmental factors: good learning environment; class size; environmental condition (peace in the locality crisis e.tc); teaching and training method, personal factors: lack of reading habit and reading plan; unwillingness to assume full responsibility; playing and wasteful time spending; interest in a course; lack of self-discipline; procrastination ; lack of desire, decision and determination; bad attitude towards school; lack of initiative and use of imagination; poor literacy skills of students; lack of self-discipline; lack of maturity; laziness or apathy; inadequate or poor exam preparation, academic factors: lack of provision of a bridge between theory and practical; heavy course workload.

The study of Borde (1998) found that age and gender influenced academic performance in varying contexts and noted that mature students performed better than the younger ones. It however observed that this comparison depended on the subject matter and types of assessment used. This was in tandem with Woodfield and EarlNovell (2006), which also found that female students out-performed their male counterparts. It attributed this partly to female students being more conscientious and less likely to miss lectures. Mercanlioglu (2010) revealed that the students who could not perform the necessities of time management effectively in their private and business lives, and were not able to keep them updated, resulted in failure and unhappiness. This was supported by the work of Comfort et al. (2014), which found out that time management distinguishes students with high academic performance from their counterparts, though this was not statistically significant. According to Sujitet al.(2006), many students found it hard to combine and organize their study and leisure time, which could be attributed to their perceived course load and stress associated with examinations.

From the foregoing, students' academic performance can be attributed to demographic, socio-economic, family background, and institution factors, which needed to be addressed for improved academic standards in any higher institution.

\subsection{Study Area}

This research was conducted in the Federal University of Technology, Akure. Ondo state as one of the states in 
south western Nigeria has 9 tertiary institutions (private and public) of which the Federal University of Technology, Akure (FUTA) is the most prominent and the only Federal University. The University was established in 1981, and has grown tremendously, stretching its academic disciplines and research across seven different schools (faculties) and over forty academic Departments, with the vision to becoming a world class University of Technology and a centre of excellence in training, research and service delivery, while its Mission is to promote technological advancement by providing conducive environment for research, teaching and learning engenders development of products that are technologically oriented, self-reliant and relevant to society.The Department of Estate Management was established in 1990/1991 academic session with eleven (11) students (four (4) students at the 100 level and seven (7) students at the 200 level)and has grown to 359 students as at 2016/2017 academic year at an average annual growth rate of $14.34 \%$. Presently, the Department offer courses leading to the award of Bachelor of Technology in Estate Management, Postgraduate Diploma (PGD), Master of Real Estate (MRE) with options in Land Management, Facilities Management and Valuation; Master of Technology (M.Tech), and Doctorate of Philosophy (PhD) in Estate Management. The Department is serviced by full time academic staff members of the Department and associate lecturers, while other Departments within and outside the school of Environmental Technology handle the remaining inter-disciplinary courses.

\section{Research Method}

Research methodology is the various steps, guidelines, and measures by which data for a particular study are sourced, collected, processed and analyzed, with a view to coming up with findings that help in achieving the research goal. The target population for the study were the Students of Estate management department of the Federal University of Technology, Akure, especially, 200 level, 300 level and 500 level students with the exemption of 100 level students because they do not have CGPA yet and 400 level students because they were on industrial training as at the time this research was carried out. The population (sampling frame) of the 200 level, 300 level and 500 level Estate Management students is 249.

The sample size was determined using the Yamane (2008) formula below;

$$
\mathrm{n}=\frac{N}{1+N(e)^{2}}
$$

Where $\mathrm{n}=$ Sample size

$\mathrm{N}=$ Total number of Estate management students

$\mathrm{e}=$ level of significance $(0.06)$

Therefore, sample size is 131 , which were selected based on a stratified random sampling technique.

Both primary and secondary data were used for this research. Structured questionnaire was the primary source of data, while secondary data was gotten from the result sheet in the Department in order to know the level of academic performance of the Students of the department.

For the purpose of this research, descriptive statistical analysis i.e. (use of frequency table and graph) was used to analyze the characteristics of students admitted into Estate Management Department, FUTA and the level of academic performance of Estate Management students in FUTA between 2007 and 2016 respectively. Multiple regression analysis was used to analyze the factors that affect the academic performance of the students.

Table 1: Operationalization of Variables

\begin{tabular}{|c|c|c|}
\hline Variable codes & $\begin{array}{ll}\text { Description } & \text { of } \\
\text { Variables } & \\
\end{array}$ & Measurement \\
\hline ACPERF & $\begin{array}{l}\text { Academic } \\
\text { Performance }\end{array}$ & Students' CGPA \\
\hline AGE & Age & $\begin{array}{l}1=14-16 \text { years; } 2=17-19 \text { years; } 3=20-22 \text { years } 4=23-25 ; \text { and } \\
5=\text { Above } 25 \text { years }\end{array}$ \\
\hline SEX & Sex & $1=$ Male $; 2=$ Female \\
\hline FAEDUBAK & $\begin{array}{l}\text { Father's educational } \\
\text { background }\end{array}$ & $\begin{array}{l}1=\text { No Formal Education; } 2=\text { First School Leaving Certificate; } 3= \\
\text { NCE/OND; } 4=\mathrm{HND} / \mathrm{BSc} ; 5=\mathrm{MSc} / \mathrm{PhD}\end{array}$ \\
\hline MONALL & Monthly allowance & $\begin{array}{l}1=\text { Less than N10,000; } 2=\mathrm{N} 10,000-\mathrm{N} 20,000 ; 3=\mathrm{N} 20,000- \\
\mathrm{N} 30,000 ; 4=\mathrm{N} 30,000 \& \text { Above }\end{array}$ \\
\hline NUCLASS & Number in class & $\begin{array}{l}1=\text { Less than } 30 ; 2=30-50 ; 3=50-70 ; 4=70-90 \\
5=90 \text { and above }\end{array}$ \\
\hline REHOURS & $\begin{array}{l}\text { personal reading } \\
\text { Hours }\end{array}$ & $\begin{array}{l}1=\text { Less than } 2 \text { hours; } 2=2-4 \text { hours } \\
3=4-6 \text { hours; } 4=6-8 \text { hours } \\
5=8-10 ; 6=\text { Above } 10 \text { hours }\end{array}$ \\
\hline PLAPERREAD & $\begin{array}{l}\text { Place of personal } \\
\text { reading }\end{array}$ & $\begin{array}{l}1=\text { Room; } 2=\text { Library; } 3=\text { Lecture theatres } \\
4=\text { others }\end{array}$ \\
\hline
\end{tabular}




\begin{tabular}{|c|c|c|}
\hline Variable codes & $\begin{array}{l}\text { Description of } \\
\text { Variables }\end{array}$ & Measurement \\
\hline UNIT & $\begin{array}{l}\text { No. Of unit in place } \\
\text { of worship }\end{array}$ & Actual \\
\hline SLEEP & $\begin{array}{l}\text { No of sleeping } \\
\text { hours/day }\end{array}$ & $\begin{array}{l}1=\text { Less than } 3 \text { hours; } 2=3-5 \text { hours } \\
3=5-7 \text { hours } 4=7-10 \text { hours }\end{array}$ \\
\hline ADMS & Mode of Admission & $1=$ Direct Entry $; 2=$ Pre-degree $; 3=\mathrm{UTME}$ \\
\hline BESTIME & Best reading time & $\begin{array}{l}\text { 1= Dawn; } 2=\text { Morning; } 3=\text { Afternoon } \\
4=\text { Night }\end{array}$ \\
\hline
\end{tabular}

\section{Result and Discussions}

This section of the research project deals with data collected from the respondents and the discussion of results. A larger percentage of the data were collected with the use of questionnaire, while some were secondary data. Out of the 131 questionnaires administered on year 2, 3 and 5 students, 106 representing $80 \%$ of the total questionnaire administered were retrieved.

The socio-demographic characteristics of the respondents help to determine the suitability of the respondents to giving favourable response as regards the topic of discussion.

Table 2:Socio-Economic Characteristics of the Respondent Students

\begin{tabular}{llll}
\hline \multirow{2}{*}{ Sex } & Characteristics & Frequency & Percentage \\
& Male & 62 & 58.5 \\
& Female & 44 & 41.5 \\
& Total & 106 & 100 \\
\hline Age & $14-16$ years & 1 & 0.9 \\
& $17-19$ years & 7 & 6.6 \\
& $20-22$ years & 31 & 29.2 \\
& 23-25 years & 45.3 \\
& Above 25 years & 48 & 12.3 \\
& Missing & 13 & 5.7 \\
& Total & 6 & 100 \\
\hline Father educational background & No formal education & 100 & 4.7 \\
& First school leaving & 5 & 25.5 \\
& NCE/OND & 27 & 12.3 \\
& HND/Bsc & 13 & 34.9 \\
& Msc/Phd & 37 & 18.9 \\
& Missing & 20 & 3,7 \\
& Total & 4 & 100 \\
\hline Family economic status & Low income & 100 & 4.7 \\
& Middle income & 5 & 83.0 \\
& High income & 88 & 10.4 \\
& Missing & 11 & 1.9 \\
& Total & 2 & 100 \\
\hline
\end{tabular}

Source; Field Survey, 2017

Data from table 2 shows that $58.5 \%$ of the respondents were male and $41.5 \%$ were female. This indicates a balanced judgment basis as the data is gender indiscriminate. Most of the respondents $(45.3 \%)$ were within ages 23-25 years. Although, Akindada (2015) opined the 16 year minimum age for university admission in Nigeria has no legal backing, it has become more or less the norm as far as varsity admission is concerned, even though a few schools break away from the norm to admit kids as young as 14 and 15 .

Also, $34.9 \%$ of the respondents were from families whose fathers were HND/B.Sc. holder, while $4.7 \%$ of the respondents' fathers had no formal education. This means majority of the respondent's Father were literate and they know the value of education.

Most of the respondents (83\%) were from families with average income economic status, while $4.7 \%$ of the respondents were from families with low economic status. Other things being equal, the economic status of families could affect the performance of students from such families because cultural display of the student is determined to a large extent by social economic background. 
Table 3:Characteristics of Students Activities

\begin{tabular}{|c|c|c|c|}
\hline \multirow[t]{9}{*}{ Number of hours of study } & Less than 2 hours & 33 & 31.4 \\
\hline & $2-4$ hours & 54 & 50.9 \\
\hline & 4-6 hours & 9 & 8.5 \\
\hline & $6-8$ hours & 1 & 0.9 \\
\hline & $8-10$ hours & 1 & 0.9 \\
\hline & Anytime & 6 & 5.7 \\
\hline & Others & 1 & 0.9 \\
\hline & Missing & 2 & 1.0 \\
\hline & Total & 106 & 100 \\
\hline \multirow[t]{8}{*}{ Place of personal reading } & Room & 62 & 59.6 \\
\hline & Library & 4 & 3.8 \\
\hline & Lecture theatre & 20 & 18.9 \\
\hline & Anywhere & 13 & 12.3 \\
\hline & Room and library & 1 & 0.9 \\
\hline & Room and lecture theatre & 4 & 3.8 \\
\hline & Missing & 2 & 0.7 \\
\hline & Total & 100 & 100 \\
\hline \multirow[t]{10}{*}{ Student CGPA } & Less than 1.5 & 1 & 0.9 \\
\hline & $1.50-1.99$ & 2 & 1.9 \\
\hline & $2.00-2.49$ & 12 & 11.3 \\
\hline & $2.50-2.99$ & 14 & 13.2 \\
\hline & $3.0-3.49$ & 20 & 18.9 \\
\hline & $3.50-3.99$ & 30 & 35.9 \\
\hline & $4.0-4.49$ & 18 & 17.0 \\
\hline & $4.50-5.00$ & 1 & 0.9 \\
\hline & Missing & 10 & 9.9 \\
\hline & Total & 106 & 100 \\
\hline
\end{tabular}

Source; Field Survey, 2017

From table $3,50.9 \%$ of the respondents read between $2-4$ hours daily, while only $0.9 \%$ of the respondent read within 8-9 hours a day. This proved wrong the previous ideology that Students of higher institution of learning read for long. This means reading for long has no place in this generation as most people hardly sit down to read beyond 4 hours a day as studying continuously for an average of 8-9 hours per day may create fatigue and overall exertion among students. Therefore, a break time while studying is necessary for refreshing individual's mind and help them enhance their overall performance.

Also, $59.6 \%$ of the respondents read in their rooms, while only $3.8 \%$ read in the library. This means that the use of library is going into extinction probably because we are in the jet age where students can access the world on their gadgets (phones, laptops etc) wherever they are, most especially in their rooms without stepping out. As it is now, a larger percentage of students do not use the Library again.

On academic performance, it can be said that most of the respondents have good academic performance as $72.7 \%$ were between GPA of 3.00-5.00.Bakare (1994) described poor academic performance as any performance that falls below a desired standard, while Sujitet al. (2006) added that, for any graduate program, a GPA of 3.0 or higher is considered an indicator of good academic performance.

Table 4: Cross-tabulation of Students' CGPA and Age

\begin{tabular}{|c|c|c|c|c|c|c|c|c|c|}
\hline \multicolumn{9}{|c|}{ Age of Students' CGPA (\%) } & \multirow[t]{2}{*}{ Total } \\
\hline Student(Yr) & $\begin{array}{l}\text { Below } \\
1.5\end{array}$ & $\begin{array}{l}1.50- \\
1.99\end{array}$ & $\begin{array}{l}2.00- \\
2.49\end{array}$ & $\begin{array}{l}2.50- \\
2.99\end{array}$ & $3.0-3.49$ & $\begin{array}{l}3.50- \\
3.99\end{array}$ & 4.00-4.49 & $\begin{array}{l}4.50- \\
5.00\end{array}$ & \\
\hline 14-16 & & & & & & & 1.1 & & 1.1 \\
\hline 17-19 & & 1.1 & & 1.1 & 1.1 & 2.2 & 1.1 & & 6.5 \\
\hline 20-22 & 1.1 & & 1.1 & 4.3 & 9.8 & 9.8 & 5.4 & & 31.5 \\
\hline 23-25 & & 1.1 & 8.7 & 6.5 & 7.6 & 14.1 & 7.6 & 1.1 & 46.7 \\
\hline Above 25 & & & 2.2 & 2.2 & 3.3 & 3.3 & 3.3 & & 14.1 \\
\hline Total & 1.1 & 2.2 & 12.0 & 14.1 & 21.7 & 29.3 & 18.5 & 1.1 & 100.0 \\
\hline
\end{tabular}

Source; Field Survey, 2017

From table 4, it can be deduced that Students between 23-25 years are the highest number of students with good academic performance (i.e. between 3.00-5.00 CGPA), which is $30.4 \%$. This could be as a result of their 
maturity and dedication, which comes with the full understanding that an undergraduate is no longer a child that is needed to be forced to read and to be serious. This corroborates Borde's (1998) findings that age influenced academic performance in varying contexts, and noted that mature students performed better than the younger ones. The study however, observed that this comparison depends on the subject matter and types of assessment used, though, Kaur, Chung, and Lee (2010) is of the opinion that age does not contribute to academic performance of university students. However, it is vivid from this study that age significantly contributes to the academic performance of students as those who are below 23 years are probably not too matured to handle academic stress, while those who are above 25 years probably have other engagements outside academics as they feel age is not on their sides to give their totality to just studying.

Table 5: Cross-tabulation of Students' CGPA and Mode of Admission

\begin{tabular}{|c|c|c|c|c|c|c|c|c|c|}
\hline \multirow{2}{*}{$\begin{array}{l}\text { Mode } \\
\text { admission }\end{array}$} & \multicolumn{8}{|c|}{ of Students' CGPA (\%) } & \multirow[t]{2}{*}{ Total } \\
\hline & $\begin{array}{l}\text { Below } \\
1.5\end{array}$ & $\begin{array}{l}1.50- \\
1.99\end{array}$ & $\begin{array}{l}2.00- \\
2.49\end{array}$ & 2.50-2.99 & $\begin{array}{l}3.0- \\
3.49\end{array}$ & $\begin{array}{l}3.50- \\
3.99\end{array}$ & $\begin{array}{l}4.00- \\
4.49\end{array}$ & $\begin{array}{l}4.50 \\
5.00\end{array}$ & \\
\hline Direct entry & & & 1.1 & & 3.2 & 6.3 & 5.3 & & 15.8 \\
\hline Pre-degree & & 2.1 & 4.2 & 4.2 & 6.3 & 10.5 & 2.1 & & 29.5 \\
\hline UTME & 1.1 & & 7.4 & 10.5 & 11.6 & 11.6 & 11.6 & 1.1 & 54.7 \\
\hline Total & 1.1 & 2.1 & 12.6 & 14.7 & 21.1 & 28.4 & 18.9 & 1.1 & 100.0 \\
\hline
\end{tabular}

Source; Field Survey, 2017

When students are admitted to a higher education institution, there is an inferred assumption that they will be capable of successfully completing the course in which they are permitted to enrol. To knowingly admit students who, for whatever reason, have no chance of academic success would be immoral. Therefore, it is necessary to have entry requirements that permit valid student selection decisions to be made (Oke et al.,2016). The entry requirements of the several modes of admission are different and this probably draws the margin in the performance of students with different modes of admission. According to this study, students who got admitted through direct entry have better academic performance compared to those who got admitted through other modes of admission as $14.7 \%$ out of $15.8 \%$ have good academic performance. This could be because they have previously attended a higher institution of learning (polytechnic, college of education etc) where they had the pre-knowledge of what is being taught in the University. So, they see lectures as revision classes, while other students struggle to familiarize themselves with the topic being taught. This corroborates with the work of Sariem et al. (2014) that students who gained admission into Pharmacy faculty through the direct entry had higher CGPAs than those who came in through the unified tertiary matriculation examination and other remedial courses. This could be as a result of the basic foundation and experience obtained by the former, which enabled them to be better equipped and prepared for the rigorous Pharmacy training. Also, from the findings, Students who got admitted through pre-degree have the least academic performance as only $18.9 \%$ out of $29.5 \%$ have good academic performance. It could be because their entry standard was not as high as that of other modes of admission and they didn't compete with multitudes that did Jamb before they got admitted as long as they met up with the pre-degree cut off marks. In conclusion, students who gained admission through direct entry have better academic performance compared to Students who gained admission through other modes.

Table 6: Cross-tabulation of Place of personal reading and Students' CGPA

\begin{tabular}{|c|c|c|c|c|c|c|c|c|c|}
\hline \multirow{2}{*}{$\begin{array}{l}\text { Place of personal } \\
\text { reading }\end{array}$} & \multicolumn{8}{|c|}{ Students' CGPA } & \multirow[t]{2}{*}{ Total } \\
\hline & $\begin{array}{l}\text { Below } \\
1.5 \\
\end{array}$ & $\begin{array}{l}1.50- \\
1.99\end{array}$ & $\begin{array}{l}2.00- \\
2.49 \\
\end{array}$ & $\begin{array}{l}2.50- \\
2.99\end{array}$ & $\begin{array}{l}3.0- \\
3.49\end{array}$ & $\begin{array}{l}3.50- \\
3.99 \\
\end{array}$ & $\begin{array}{l}4.00- \\
4.49\end{array}$ & $\begin{array}{l}4.50- \\
5.00 \\
\end{array}$ & \\
\hline Room & 1.1 & & 11.6 & 6.3 & 6.3 & 17.9 & 13.7 & 1.1 & 57.9 \\
\hline Library & & & & 2.1 & 2.1 & & & & 4.2 \\
\hline Lecture theatre & & & 1.1 & 6.3 & 6.3 & 4.2 & 2.1 & & 20.0 \\
\hline Any where & & 2.1 & & & 5.3 & 3.2 & 2.1 & & 12.6 \\
\hline Room and library & & & & & & 1.1 & & & 1.1 \\
\hline $\begin{array}{l}\text { Room and lecture } \\
\text { theatre }\end{array}$ & & & & & & 3.2 & 1.1 & & 4.2 \\
\hline Total & 1.1 & 2.1 & 12.6 & 14.7 & 20.0 & 29.5 & 18.9 & 1.1 & 100.0 \\
\hline
\end{tabular}

Source; Field Survey, 2017

From table 6 , students who read in their room are the highest number of students with good academic performance (between 3.00 and 5.00) with $39 \%$ of respondents. Of great concern is the non-usage of the Library by students despite Darling-Hammond and Synder's (2001) claim that availability of adequate research equipment and teaching materials in libraries and laboratories could significantly improve students' performance. With this research, it's obvious that $21^{\text {st }}$ century students no longer care about the adequate research equipment and teaching materials in libraries, as only few make use of the library, and none of those who make use of it have a CGPA above 3.49. However, Abbasi and Mir (2012) explained that students themselves play critical roles in getting good grades and must therefore explore all opportunities available within their academic 
environment, which includes the Library. With the present situation of things, easy access to internet, journals and textbook online make students discard the opportunities available in the Library.

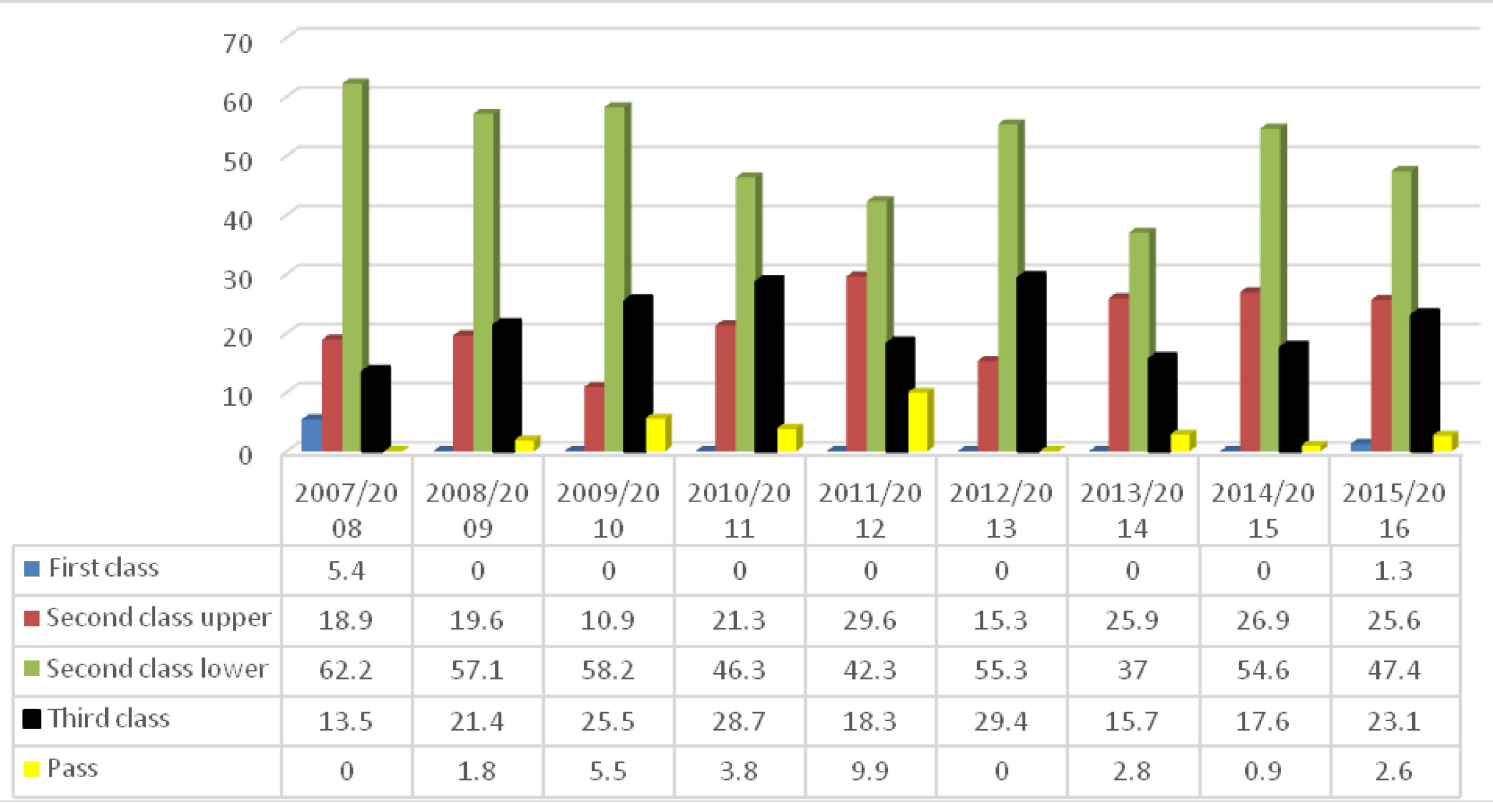

Source: Convocation brochure, 2008 - 2016

Figure 1: Level of academic performance of Students between 2007 and 2016

From figure 1, as the year progressed, judging with the number of those who graduated with second class upper and above, there was an improvement in academic performance in the department. It should be noted that there is a range of factors affecting the quality of performance of undergraduate students. As observed, first class was in extinction for 8 years, and there were variations in other classes of degree. There are some students who devoted most of their times to their studies especially during examination periods and yet, performed below expectation in their final examinations. This can be attributed to undue stress and a whole lot of other factors. Factors such as parents' support and type of parenting (single or two parenting system) could also account for variation in student's performance (Eweniyi, 2002; Okolieet al., 2014).In identifying the factors affecting the quality of academic success, a series of variables ought to be considered (Waters and Marzano,2006).

These days, it is not uncommon for students to blame their lecturers when they fail and sometime claim that examination is not a true test of knowledge. Agreeing with this assertion will only mean there is no need for teaching because examination as a method of evaluation is used to get the feedback of progress from the learners. Anikweze (2005) argued that evaluation is a pertinent aspect of good teaching and learning because no matter how efficient the teacher is, how intelligent the students are, how adequate the auto-visual equipment, if no provision is made for some evaluation of progress, the teaching effort may be completely invalidated. Examination, which according to Tobih (2012)is an organized activity aimed at determining the cumulative or broad knowledge in a students' educational development, have been widely used to evaluate student's success and performance in formal school settings. At a higher education level, it helps to establish the integrity of the degree or certificate awarded by any higher institution (Oke, 2016).

Some factors might have affected the academic performance of Students between 2008 and 2016 academic sessions. According to this study, there was an increase in the number of students who graduated with second class upper division, which is a show of academic improvement. However, it should also be noted that there was no first class in the Department for 8 years after the two (2) first class students recorded in 2007/2008 academic session. This is a big reason to worry and at the same time assess the factors that may be responsible for such a trend.

Table 7: Model Summary of Regression analysis

\begin{tabular}{lllll}
\hline Model & R & R Square & Adjusted R Square & Std. Error of the Estimate \\
\hline & 0.89 & 0.831 & .799 & .688
\end{tabular}

Source: Field Survey, 2017

Table 7 reveals that there is a strong relationship between the independent variables and student's academic performance (CGPA) as shown by the correlation coefficient (R) of 0.89 equivalents to $89 \%$ relationship. Also, the result shows that $83.1 \%$ variation in dependent variable (CGPA) is caused by the selected independent variables, leaving $26.9 \%$ causal effect for other variables that were not considered in this model. 
Table 8: Analysis of Variance

\begin{tabular}{llllll}
\hline Model & Sum of Squares & Df & Mean Square & F & Sig. \\
\hline Regression & 42.571 & 12 & 2.184 & 28.712 & $.033^{\mathrm{b}}$ \\
Residual & 62.797 & 77 & 4.643 & & \\
Total & 105.368 & 88 & & & \\
\hline
\end{tabular}

Source: Field Survey, 2017

From the ANOVA results in table 8 , the probability value of 0.033 was obtained implying that the regression model was significant in predicting the relationship between student's CGPA and the predictor variables as it was less than $\alpha=0.05$. The F-test of 28.712, which is referred to as the F-change is used to test the R-square change to know the level of prediction. As the value moves positively away from zero, the better the predictability of the model. The result in the table revealed that the variables added in the step significantly improved the prediction of student's CGPA. Thus, the model provides a better fit than the intercept-only model.

Table 9: Analysis of the factors that affects Students' academic performance

\begin{tabular}{|c|c|c|c|c|c|}
\hline \multirow[t]{2}{*}{ Model } & \multicolumn{2}{|c|}{$\begin{array}{l}\text { Unstandardized } \\
\text { Coefficients }\end{array}$} & \multirow{2}{*}{$\begin{array}{l}\text { Standardized } \\
\text { Coefficients }\end{array}$} & \multirow[t]{2}{*}{$\mathbf{T}$} & \multirow[t]{2}{*}{ Sig. } \\
\hline & $\mathrm{B}$ & Std. Error & & & \\
\hline (Constant) & 2.320 & .991 & & 2.342 & .022 \\
\hline Age of the student & .381 & .126 & .340 & $3.027 *$ & .003 \\
\hline Sex of the student & -.018 & .205 & -.010 & -.088 & .930 \\
\hline Parental support & .291 & .119 & .310 & $3.039 *$ & .004 \\
\hline Father educational background & .021 & .081 & .028 & .263 & .793 \\
\hline Monthly allowance & -.035 & .073 & -.052 & -.477 & .634 \\
\hline Number in class & -.032 & .068 & -.054 & -.469 & .641 \\
\hline $\begin{array}{l}\text { No. of hours devoted for } \\
\text { Personal reading }\end{array}$ & .017 & .291 & .235 & $2.282 *$ & .001 \\
\hline Place of personal reading & -.065 & .044 & -.161 & -1.485 & .142 \\
\hline $\begin{array}{l}\text { No .of. unit in place of worship } \\
\text { (Extra Curricular activity) }\end{array}$ & -.005 & .097 & -.005 & $4.901 *$ & .045 \\
\hline Sleeping hours & .110 & .126 & .093 & .872 & .386 \\
\hline Mode of admission & .039 & .136 & .033 & .290 & .773 \\
\hline Best reading time & .000 & .000 & .038 & .350 & .727 \\
\hline
\end{tabular}

Source: Field Survey, 2017

Table 9 shows that a unit increase in the age of the student would result in an increase by 0.381 unit of their academic performance since it $\mathrm{p}$ value is less than 0.05 i.e. 0.03 . According to the analysis, Students between the ages of 23-25 years have the best academic performance compared to others of different age categories. This could be as a result of their maturity and dedication which comes with the full understanding that an undergraduate is no longer a child needed to be forced to read and to be serious. Although, Kaur, Chung, and Lee (2010) observed that age does not significantly contribute to academic performance of university students. However, from this research it is vivid that age significantly contributes to the academic performance of Students as this factor has a great impact in determining their level of academic performance.

Also, a unit increase in Parental support would result in an increase by 0.291 unit of their academic performance, and this significant at 0.04. This means Parental support have high impact on academic performance of students. This further corroborates Hale (2001), Goddard (2003) and Barnard (2004) findings, which revealed that academic achievement of students depends on their parental care and support as parents tend to help inspire, support, care for, and sustain their children in education, thus helping them to succeed academically. This could be as a result of the natural bond that exists between Parent and their children. Though, this finding is contrary to the view of Schmelzer, Figler and Brozo (1987) that the responsibility for academic success rests entirely with students, and that they need to acquire those skills that will allow them to succeed even when they encounter poor instructions. However, the finding supports Irvine (1999) and Bamidele (2013) assertions that teachers/lecturers and Parents are key factor for student's success. Thus, it should be noted that an average child gets motivated when he has the assurance of the support of his parents on his path to greatness.

From Table 9, a unit increase in the number of hours devoted for Personal reading would result in an increase by 0.017 unit of Students academic performance (CGPA). This is statistically significant with a p-value of 0.01 . Results from the study shows that lack of reading habit and reading plan can adversely affect academic performance. According to Lay and Schouwenburg (1993), extensive course loads and the comprehensive information covered in school curricula should necessitate the use of effective personal study strategies for 
academic success. No matter how brilliant a Student is, if he fails to study alone, such a student may never achieve the optimum success required. This is in agreement with Fraser and Killen (2003) research where there exist a strong agreement between students and lecturers view of inadequate or poor examination preparation being the major factor affecting students' performance. This is understandable as poor examination preparation can be as a result of lack of concentration and lack of reading habit and reading plan on the part of the student. This also corroborates Benford and Gess-Newsome (2006) findings that student academic under-preparedness is one of the factors responsible for students' failure in Northern Arizona University.

From the table, an increase in the Number of units involved in place of worship (extra curricula activity) would result in a decrease by -0.005 unit of Students academic performance with a p-value of 0.045 . When Students get too involved in diverse units activities in their place of worship, not minding the religion, they get to use the time meant for studying for one unit meeting or the other, even the time left, they tend to use it to rest first before thinking of reading, which in return affects their academic performance. Its root can be traced to poor time management from Students' angle. A study by Mercanlioglu (2010) showed inability to perform the necessities of time management effectively in private and business lives, and inability to keep oneself updated, results in failure and unhappiness. Time consumed can never be taken back. Therefore, time should be considered consciously, with good planning, and should be used wisely in order for success to be obtained and productivity to be increased.

Finally, a unit increase in factors like Sex of the student, Father educational background, Monthly allowance, Number in class, Place of personal reading, Sleeping hours, Mode of admission, Best reading time toward students do not significantly affect the students' academic performance, even if they have a way of contributing to the Student's academic performance.

\section{Conclusion}

This study analyzed the academic performance (CGPA) of students in Estate Management Department, FUTA with a view to understanding the factors that influence students academically. Finding revealed an increase in the students' academic performance recorded as the years went by as more students graduated with second class upper. It should be noted that there was no first class in the department for 8 years after the 2 first class recorded in 2007/2008 academic session. Finally, factors like age of students, parental support, number of hours devoted for personal reading, and number of extra curricula activities significantly affect student's academic performance. Thus, it is recommended that Parents should be made aware of their roles in the success of their wards/students, while Students themselves are to be self-motivated so as to cultivate good reading habits. Understanding some of these factors for success should lead to innovative ways of providing a more successful academic atmosphere in the Nigerian Universities.

\section{References}

Aduke, F. (2015). Time Management and Students Academic Performance in Higher Institution, Nigeria - A Case Study of Ekiti State, 3(2). https://doi.org/10.5296/ire.v3i2.7126

Barnard, W. M. (2004). Parent involvement in elementary school and educational attainment. Children and Youth Services Review, 6(26): 39- 62.

Benford, R. \&Gess-Newsome, J. (2006). Factors Affecting Student Academic Success in Gateway Courses at Northern Arizona University. Center for Science Teaching and Learning Northern Arizona University.

Braunstein, A. (2002). Factors determining success in a graduate business program. College Student Journal, 36 : 471-484.

Borde S.F. (1998). Predictors of student academic performance in the introductory marketing course. Journal of Education for Business. $73 \quad$ (5): $\begin{array}{llllll}302 & - & 307 . & \text { Available at }\end{array}$ http://www.libraries.sta.uwi.edu/journals/ojs/index.php/cts/article/viewFile

Crosnoe, R., Johnson, M. K., \& Elder, G. H. (2004). School size and the interpersonal side of education: An examination of race/ethnicity and organizational context. Social Science Quarterly, 85(5): 1259-1274.

Eweniyi, G. D (2002). The Impact of Family Structure on University Students' Academic Performance. Olabisi Onabamijo University, Ago-Iwoye.

Fraser, W. J. \& Killen, R. (2003). Factors influencing academic success or failure of first-year and senior university students: do education students and lecturers perceive things differently? South African Journal of Education, 23(4): 254 - 260

Goddard, R. D. (2003). Relational networks, social trust, and norms: A social capital perspective on students' chances of academic success. Journal of Educational Evaluations \& Policy Analysis, 25(7): 59-74.

Hale, J. (2001). Learning while black creating educational excellence for African American children. Baltimore: The John Hopkins University Press.

Irvine, J. (1990). Black students and school failure policies, practices, and prescriptions. New York: Greenwood Press. 
Kaur, K., Chung, H. T. \& Lee, N. (2010). Correlates of Academic Achievement for Master of Education Students at Open University Malaysia. Paper presented in 6th Pan Commonwealth Forum on Open Learning, 24th-28th November, 2010, Kochi, India.

Okolie U. C., Inyiagu E. E., Elom E. N., Ndem J. U. \&Nwuzo A. C. (2014). Effect of Home Background onAcademic Performance of Technical College Students in Ebonyi State, Nigeria. The International Journal of Humanities \& Social Studies, 2(5): 76-82

Schmelzer R. V., Schmelzer C. D., Figler R. A. \&Brozo W. G. (1987). Using the critical incident technique to determine reasons for success and failure of university students. Journal of College Student Personnel,28: 261-266

Sogbetun, A. (1981). Teachers \& students opinion about the causes of poor academic performance in secondary schools. Unpublished M.Ed project Ibadan: University of Ibadan.

Tobih, D. O. (2012). Students' appraisal of the conduct of undergraduate examinations in Obafemi Awolowo University Ile-Ife, Nigeria. Ife Journal of Theory and Research in Education, 3(7): 86-97

Waters, T. J., \& Marzano, R. J. (2006). School district leadership that works: The effect of superintendent leadership on student achievement. Mid-Continent Research for Education and Learning. Retrieved

Ali, H.O. (2013). Factors Affecting Students' Academic Performance inMathematical Sciences Department in Tertiary Institutions in Nigeria. US-China Education Review A. 3(12), 905 - 913

Abbasi, A. R., \& Mir, G. M. (2012). Impact of teacher's ability, students' work ethics and institutional environment on student performance at university of Gujrat. Middle-East Journal of scientific Research,2(4), 572-579.

Bacon, D.R., \& Beans, B. (2006), GPA in research studies: An invaluable but neglected opportunity, Journal of marketing Education, 28, 35-42.

Darling-Hammond, L, Berry, B., \&Thoreson, A. (2002). Does teacher certification matter? Evaluating the evidence. Educational Evaluation and Policy Analysis, 23(91), 57-77.

Devadoss, S., \& Foltz, J. (1996). Evaluation of factors influencing students' attendance and performance. American Journal of Agricultural Economics, 78(3), 499-507.

Gainen, J. (1995). Barriers to success in quantitative gate keeper courses. In J. Gainen, \& E. W. Williamson (Eds.), Fostering student in quantitative gateway courses (pp. 5-14). San Francisco

Hard, N., \& El-Shaarawi, A. (2006). Factors affecting students' performance. Munich personal Repec Archive paper No. 13621.

Heinesen, E. (2010). Estimating class-size effects using within school variation in subject specific classes: An important interaction. Advances in Health Sciences Education, 5(3), 197-205.

Kobrin, J.L., Patterson, B.F., Shaw, E.J., Mattern, K.D., \&Barbuti, S. M., (2008). Validity of SAT for predicting first-year college grade point average. New York, N.Y: College Board

Park, K. H., \& Kerr, O. M. (1990). Determinants of academic performance: A multinomial logit approach. Journal of Economic Education, 21(2), 101-111

Lizzio, A., Wilson, K., \& Simons, R. (2002). University students' perception of learning environment and academic outcomes: Implications for theory and practice. Studies in Higher Education, 27(1), 27-52

Romer, P. (1993) Do students go to class? Should they go? Journal of economic perspectives, 7(3), 167-174.

Woodfield, R., \& Earl- Novell, S. (2006). An assessment of the extent to which subject variation in relation to the award of first class degrees between the Arts and Sciences can explain the 'gender gap'. British Journal of sociology of Education, 27(3), 355-372.

Zimmerman, B. J., Bandura, A., \& Martinez-Pons, M. (1992). Self- motivation for academic attainment: The role of self-efficacy beliefs and personal goal setting. American Educational Research Journal, 29(3), 663676.

Lay C. and Schouwenburg H. Trait procrastination, time management and academic behavior.(1993). $J$ SocBehav Pers. 84:647-62. Available at www.ncbi.nlm.nih.gov/pmc/articles/PMC1636912

Sujit SS., Monali B., Sail K. (2006). Factors That Affect Academic Performance Among Pharmacy Students. Am J Pharm Educ. 70(5): 104.http://www.ncbi.nlm.nih.gov/pmc/articles/PMC1637000/

SariemCN., Ibrahim MA., Auta A. and Ndukwe HC. (2012). Evaluation of Student-Academic Adviser Relationship in a Nigerian University. African Journal of Pharmaceutical Research and Development. 4(2):38-43.

Mercanlioglu I. (2010). The relations of time management to academic performance of master level students. International Journal of Business and Management Studies. 2(1).

Cambridge University Reporter. (2003). Indicators of academic performance. Retrieved on August 8, 2007 from http://www.admin.cam.ac.uk/reporter/2002-3/weekly/5913/ 